\title{
Kepemimpinan, Kompensasi, Disiplin Kerja Motivasi dan Kinerja Pegawai
}

\author{
Indah Pertiwi ${ }^{(1)}$ \\ A.A.N Oka Suryadinata Gorda ${ }^{(2)}$ \\ Universitas Pendidikan Nasional ${ }^{(1)}$ \\ Universitas Pendidikan Nasional ${ }^{(2)}$ \\ tiwik_oke@yahoo.co.id ${ }^{(1)}$ \\ okagorda@gmail.com ${ }^{(2)}$
}

\begin{abstract}
The purpose of this study is to find out and analyze Leadership, Compensation, Work Discipline, Motivation and Employee Performance. The population used in this study is the Regional Office X of the Denpasar State Civil Service Agency staff of the with 85 employees. The sample in this study is the entire population because the number of employees is less than 100. Data collection is done using the questionnaire method. The analysis technique used is PLS (Partial Least Square). The results of the study showed that Leadership, Work Discipline, Motivation had a significant positive effect on Compensation and Employee Performance. This research is expected to be a reference and consideration for the Regional Office $X$ of the Denpasar State Civil Service Agency to provide opportunities for employees to develop their ability to perform well and facilitate employees in increasing work motivation.

Keywords : Leadership; Compensation; Work Discipline; Motivation and Employee Performance
\end{abstract}

\begin{abstract}
ABSTRAK
Tujuan penelitian ini adalah untuk mengetahui dan menganalasis Kepemimpinan, Kompensasi, Disiplin Kerja, Motivasi dan Kinerja Pegawai. Populasi yang digunakan dalam penelitian ini adalah pegawai Kantor Regional X Badan Kepegawaian Negara Denpasar dengan jumlah 85 pegawai. Sampel dalam penelitian ini yaitu seluruh populasi karena jumlah pegawai kurang dari 100. Pengumpulan data dilakukan dengan menggunakan metode kuesioner. Teknik analisis yang digunakan adalah PLS (Partial Least Square). Hasil penelitian menunjukkan bahwa Kepemimpinan, Disiplin Kerja, Motivasi berpengaruh positif singnifikan terhadap Kompensasi dan Kinerja Pegawai. Penelitian ini diharapkan dapat menjadi refrensi dan bahan pertimbangan Kantor Regional X Badan Kepegawaian Negara Denpasar untuk memberikan kesempatan kepada pegawai untuk mengembangkan kemampuan diri untuk berprestasi serta memfasilitasi pegawai dalam meningkatkan motivasi kerja.
\end{abstract}

Kata kunci : Kepemimpinan; Kompensasi; Disiplin Kerja; Motivasi dan Kinerja Pegawai 


\section{PENDAHULUAN}

Dalam era persaingan usaha yang semakin ketat, kinerja yang dimiliki pegawai dituntut untuk terus meningkat. Salah satu langkah untuk mempertahankan atau meningkatkan kinerja pegawai dapat dilakukan dengan mengevaluasi kinerja pegawai dan melakukan serangkaian perbaikan agar selalu meningkatkan kualitas pegawai tersebut sehingga perusahaan tumbuh dan unggul dalam persaingan, atau minimal tetap dapat bertahan.

Sumber daya manusia mempunyai peranan yang sangat penting, dalam interaksinya dengan faktor modal, material, metode, dan mesin Hal ini, sebagaimana yang dikemukakan oleh Snyder (1989) bahwa "Manusia merupakan sumber daya yang paling bernilai, dan ilmu perilaku menyiapkan banyak teknik dan program yang dapat menuntun pemanfaatan sumber daya manusia secara lebih efektif."

Kepemimpinan adalah segala sesuatu yang menggerakkan kegiatan-kegiatan menjadi lebih sukses. Kepemimpinan dapat diartikan sebagai proses pemberian contoh oleh pemimpin kepada pegawai dalam mencapai tujuan organisasinya. Kepemimpinan juga merupakan proses yang berpengaruh dalam keaktifan kelompok untuk pencapaian tujuan.

Kompensasi merupakan salah satu alasan dan motivasi utama mengapa pegawai bekerja. Pegawai menggunakan pengetahuan, keterampilan, tenaga, waktu dan komitmennya, bukan semata-mata ingin membangkitkan atau mengabdikan diri kepada organisasi, melainkan tujuan lain yang ingin diraihnya, yaitu mengharapkan imbalan atau balas jasa atas kinerja dan produktivitas kerja yang dihasilkan (2017:217).

Disiplin Kerja sangat penting untuk pertumbuhan organisasi, terutama digunakan untuk memotivasi pegawai agar mendisiplinkan diri dalam melaksanakan pekerjaan baik secara perseorangan maupun secara kelompok. Disiplin juga bermanfaat untuk mendidik pegawai dalam mematuhi dan menyenangi peraturan, prosedur, serta kebijakan yang ada sehingga menghasilkan kinerja yang baik. Kedisiplinan merupakan fungsi operatif Manajemen SDM yang terpenting karena semakin baik baik disiplin pegawai maka semakin tinggi tingkat prestasi yang dapat dihasilkan. Tanpa disiplin pegawai yang baik, sulit bagi organisasi perusahaan mencapai hasil yang optimal (2017:332; Yudiastra dan Darma, 2015).

Memahami motivasi karyawan secara tepat merupakan pekerjaan yang sulit. Akan tetapi, organisasi perlu mengidentifikasi sasaran dan kebutuhan yang melatar belakangi perilaku karyawan. Berbagai teori motivasi menyatakan bahwa keinginan atau kebutuhan setiap orang berbeda-beda, di samping itu juga cara memenuhi kebutuhan tersebut juga sangat beragam. 
Penilaian pekerjaan adalah suatu metode untuk membandingkan berbagai pekerjaan dengan menggunakan prosedur-prosedur formal dan sistematis untuk menentukan urutan pekerjaan-pekerjaan yang lainnya. Hasil dari penilaian ini disebut sebagai kinerja, yang dapat dijadikan sebagai dasar untuk memberikan suatu upah yang adil.

Badan Kepegawaian Negara atau yang bisa disingkat BKN adalah Lembaga Pemerintah Non Kementrian Indonesia yang bertugas melaksanakan tugas pemerintah di bidang manajemen kepegawaian. Berdasarkan Peraturan Kepala BKN No : 36 Tahun 2014 tentang Organisasi dan Tata Kerja Kantor Regional BKN, Tugas Kantor Regional X BKN di Denpasar: "Menyelenggarakan sebagian tugas dan fungsi BKN di bidang Pembinaan dan Penyelenggaraan manajemen Aparatur Sipil Negara (APN) di wilayah kerjanya. Fungsi Kantor Regional BKN X Denpasar yaitu Koordinasi, bimbingan, pemberian petunjuk teknis dan pengendalian terhadap pelaksanaan peraturan perundang-undangan di bidang kepegawaian; Pemberian pertimbangan dan atau penetapan mutasi kepegawaian bagi PNS Pusat dan Daerah di wilayah kerjanya sesuai peraturan perundang-undangan yang berlaku; Penetapan pensiun PNS Pusat dan penetapan status kepegawaian di wilayah kerjanya; Pemberian pertimbangan Pensiun PNS Daerah dan penetapan status kepegawaian diwilayah kerjanya; Penyelenggaraan dan pemeliharaan jaringan informasi data kepegawaian PNS instansi pusat dan intansi daerah; Penetapan mutasi PNS Provinsi/Kabupaten/kota ke instansi pusat atau ke instansi Daerah; Pembinaan, fasilitasi, evaluasi penilaian kinerja dan penyusunan standar kompetensi Pegawai ASN di wilayah kerjanya; Pengelolaan teknologi informasi penilaian kinerja pegawai ASN; dan Pelaksanaan tugas lain yang diberikan oleh Kepala BKN. Kepemimpinan sangat diperlukan untuk meningkatkan daya saing di Kantor Regional X Badan Kepegawaian Negara Denpasar maka elemen penting dalam sistem manajemen selain motivasi keja adalah kepemimpinan. Berdasarkan uraian tersebut, maka dapat diangkat judul : Kepemimpinan, Kompensasi, Disiplin Kerja, Motivasi dan Kinerja Pegawai di Kantor Regional X Badan Kepegawaian Negara Denpasar. 


\section{Kepemimpinan}

Kepemimpinan merupakan hubungan dimana satu orang yakni pemimpin mempengaruhi pihak lain untuk bekerja sama secara suka rela dalam usaha mengerjakan tugastugas yang berhubungan untuk mencapai hal yang diinginkan oleh pemimpin tersebut (Anoraga dan Widiyanti, 2003; Wiandari dan Darma, 2017). Kepemimpinan diterjemahkan ke dalam istilah sifat-sifat, perilaku pribadi, pengaruh terhadap orang lain, pola-pola, interaksi, hubungan kerja sama antarperan, kedudukan dari satu jabatan administratif, dan persuasif, dan persepsi dari lain- lain tentang legitimasi pengaruh (Wahjosumidjo; 2005; Angka dan Darma, 2016). (Miftah Thoha 2010:9; Dewi dan Darma, 2016) mendefinisikan kepemimpinan adalah kegiatan untuk memengaruhi perilaku orang lain, atau seni memengaruhi perilaku manusia baik perorangan maupun kelompok. Dengan demikian dapat disimpulkan bahwa kepemimpinan adalah upaya mempengaruhi banyak orang melalui komunikasi untuk mencapai tujuan, cara mempengaruhi orang dengan petunjuk atau perintah, tindakan yang menyebabkan orang lain bertindak atau merespon dan menimbulkan perubahan positif, kekuatan dinamis penting yang memotivasi dan mengkoordinasikan organisasi dalam rangka mencapai tujuan, kemampuan untuk menciptakan rasa percaya diri dan dukungan diantara bawahan agar tujuan organisasional dapat tercapai.

\section{Kompensasi}

Wibowo (2007) mengemukakan bahwa kompensasi merupakan kontra prestasi terhadap penggunaan tenaga atau jasa yang lebih diberikan oleh tenaga kerja. Kompensasi merupakan jumlah paket yang ditawarkan organisasi kepada pekerja sebagai imbalan atas penggunaan tenaga kerja. Kompensasi adalah semua pendapatan yang berbentuk uang, barang langsung maupun tidak langsung yang diterima karyawan sebagai imbalan atas jasa yang diberikan kepada perusahaan (Hasibuan, 2011 : 118). Kompensasi berbentuk uang artinya kompensasi di bayar dalam bentuk uang kartal kepada karyawan bersangkutan. Kompensasi berbentuk barang artinya kompensasi dibayar dengan barang. Menurut Rivai dan Sagala (2011) Kompensasi adalah sesuatu yang diterima karyawan sebagai pengganti konstribusi jasa mereka pada perusahaan. J.Long dalam Widodo (2014) berpendapat bahwa Kompensasi adalah bagian dari reward yang hanya berkaitan dengan bagian ekonomi, tetapi sejak adanya keyakinan bahwa perilaku individual dipengaruhi oleh system dalam spectrum yang lebih luas maka system kompensasi tidak dapat terpisah dari keseluruhan system reward yang disediakan oleh organisasi. Sastrohadiwiryo (2015) adalah mengatakan bahwa kompensasi adalah imbalan jasa atau balas jasa yang diberikan oleh organisasi kepada para tenaga kerja karena tenaga kerja 
tersebut telah memberikan sumbangan tenaga dan pikiran demi kemajuan organisasi guna mencapai tujuan yang telah ditetapkan. Dengan demikian dapat disimpulkan bahwa kompensasi adalah semua pendapatan yang berbentuk uang, barang langsung atau tidak langsung yang diterima karyawan sebagai imbalan atas jasa yang diberikan kepada perusahaan.

\section{Disiplin Kerja}

Singodimedjo (2002), mengatakan disiplin adalah sikap kesediaan dan kerelaan seseorang untuk mematuhi dan kerelaan seseorang untuk mematuhi dan menaati norma-norma peraturan yang berlaku di sekitarnya. Hasibuan (2005) berpendapat disiplin adalah kesadaran dan kesediaan seseorang untuk mematuhi semua peraturan organisasi dan norma-norma sosial yang berlaku. Disiplin kerja pegawai negeri mutlak harus dijalankan dan ditegakkan demi tumbuh berkembangnya suatu aparatur pemerintah dalam mengamalkan tugas dan tangung jawab yang telah dipercayakan bangsa dan Negara kepada pegawai negeri oleh karena itu sudah menjadi kewajiban setiap pegawai untuk menegakkan disiplin (Sondang;2008). Menurut Davis dalam Sinambela (2012), Disiplin adalah penerapan pengelolaan untuk memperteguh dan melaksanakan pedoman-pedoman organisasi. Disiplin belum dapat dinyatakan efektif bekerja bilamana penampilan kedisiplinan itu hanya berdasarkan ketakutan. Disiplin dalam arti sejati adalah hasil dari interaksi norma-norma yang harus dipatuhi. Norma-norma itu tidak lain hanya bersangkutan dengan ukuran legalistik melainkan berkaitan dengan etika dan tata krama. Dengan demikian dapat disimpulkan bahwa disiplin kerja adalah suatu yang kemampuan yang akan berkembang dalam kehidupan kesehariannya seseorang atau kelompok (organisasi) dalam bertaat azas, peraturan, norma-norma, dan perundang-undangan untuk melakukan nilainilai kaidah tertentu dan tujuan hidup yang ingin dicapai oleh mereka dalam bekerja.

\section{Motivasi}

Menurut Berelson dan Stener (dalam Sofiah nur. 2003:14) mendifinisikan motivasi sebagai suatu keadaan di dalam diri seseorang yang mendorong, mengangtifkan atau menggerakkan, dan mengarahkan perilaku pada tujuan. Menurut Mc Donald, dalam Sudirma (2007) mengatakan bahwa motivasi adalah perubahan energi dalam diri seseorang yang ditandai dengan munculnya "filing" dan ddahului dengan tanggapan terhadap adanya tujuan. Menurut Sudirman (2007) motiv yang diartikan sebagai penggerak yang mendorong seseorang melakukan aktivitas-aktivitas tertentu untuk mencapai satu tujuan. Motivasi menurut Malayu S.P Hasibuan (2008:95) adalah pemberian daya penggerak yang menciptakan kegairahan kerja seseorang agar mereka mampu berkerjasama, bekerja efektif dan terintergrasi dengan segala 
daya upayanya untuk mencapai kepuasan. Jadi motivasi adalah pemberian kegairahan bekerja kepada para pegawai. Motivasi berasal dari kata movere yang berarti menggerakkan atau dorongan. (Diperkuat dengan hasil penelitian dari Widiatmika dan Darma, 2018)

\section{Kinerja Pegawai}

Kinerja atau prestasi kerja adalah hasil kerja secara kualitas dan kuantitas yang dicapai oleh seorang pegawai dalam melaksanakan tugasnya sesuai dengan tanggung jawab yang diberikan kepadanya (Anwar Prabu Mangkunegara, 2006:67; Dewi dan Darma, 2017). Kinerja karyawan adalah hasil dari proses pekerjaan tertentu secara berencana pada waktu dan tempat dari karyawan serta organisasi bersangkutan (Mangkuprawira dan Hubeis, 2007:153). Menurut Soedjono (2008:195) Kinerja adalah hasil kerja yg dihasilkan oleh pegawai atau perilaku yang nyata yang ditampilkan sesuai dengan perannya dalam organisasi”. Lijan Poltak SInambela, dkk (2011) mengemukakan bahwa kinerja pegawai didefinisikan sebagai pegawai dalam melakukan sesuatu keahlian tertentu. Dengan demikian dapat disimpulkan bahwa kinerja adalah merupakan hasil keseluruhan pekerjaan secara kuantitas maupun kualitas yang telah dilakukan seorang pegawai dalam mencapai apa yang menjadi tujuan suatu lembaga atau instansi.

\section{Kerangka Konseptual}

Dari Uraian Kerangka Konseptual tersebut di atas dapat dijelaskan melalui variabel Kepemipinan, Kompensasi, Disiplin Kerja dan Motivasi Terhadap Kinerja Pegawai secara skematis digambarkan seperti di bawah ini : 




Gambar 2.1 Kerangka Konseptual

Kepemimpinan, Kompensasi, Disiplin Kerja, Motivasi dan Kinerja Pegawai di Kantor Regional X Badan Kepegawaian Negara Denpasar

\section{Hipotesis}

Berdasarkan pada landasan teori dan kerangka pemikiran di atas, maka hipotesis dalam penelitian ini adalah sebagai berikut :

$\mathrm{H} \quad$ : Semakin baik Kepemimpinan maka semakin baik Kompensasi.

H2 : Semakin baik Motivasi maka semakin baik Kompensasi.

H3 : Semakin baik Disiplin Kerja maka semakin baik Kompensasi.

H4 : Semakin baik Kepempinan maka semakin baik Kinerja Pegawai.

H5 : Semakin baik Kompensasi maka semakin baik Kinerja Pegawai.

H6 : Semakin baik Disiplin Kerja maka semakin baik Kinerja Pegawai.

H7 : Semakin baik Motivasi maka semakin baik Kinerja Pegawai.

\section{METODE PENELITIAN}

Penelitian ini akan dilaksanakan pada lingkungan Kantor Regional X Badan Kepegawaian Negara yang terletak di jalan By Pass Ngurah Rai No 646 Pesanggaran Denpasar. Adapun alasan peneliti memilih lokasi tersebut dikarenakan mengingat pentingnya kepemimpinan, kompensasi, disiplin kerja, motivasi dan kinerja pegawai serta mengetahui peningakatan disiplin kerja, kualitas dan kuantitas pekerjaan pegawai di sebuah Instansi Kantor Regional X Badan Kepegawaian Negara Denpasar. Selain itu peneliti memilih lokasi tersebut juga karena tersedianya data yang memadai sehingga dapat menghemat biaya, waktu, dan tenaga. 
Data dikumpulkan menggunakan instrumen kuesioner. Kuisioner adalah daftar pertanyaan yang diberikan kepada orang lain yang bersedia memberikan respon sesuai dengan permintaan peneliti. Selanjutnya orang yang bersedia memberikan respon tersebut disebut responden atau sampel. Dalam memberikan respon atau jawaban yang diminta oleh angket responden tanpa merasa khawatir karena kerahasiaan identitas tidak akan dipublikasikan. Kuesioner menggunakan skala dengan jawaban 1 (sangat tidak setuju) sampai 10 (sangat setuju).

Penelitian ini menggunakain teknik analisis data dengan menggunakan software SmartPLS dijalankan dengan media komputer. PLS merupakan analisis persamaan structural berbasis varian yang secara simultan dapat melakukan pengujian model pengukuran sekaligus pengujian model structural. Model pengukuran digunakan untuk uji validitas dan reabilitas sedangkan model structural digunakan untuk uji kausalitas (pengujian hipotesis dengan model prediksi). Ghozali (2015:10) menjelaskan bahwa PLS adalah metode analisis yang bersifat soft modeling karena tidak mendasarkan pada asumsi data harus dengan skala pengukuran, distribusi data (distribution free) dan jumlah sampel tertentu yang berarti jumlah sampel dapat kecil (dibawah 100 sampel).

\section{PEMBAHASAN}

Penelitian ini menggunakan model persamaan struktural dengan pendekatan Partial Least Square (PLS ) sebagai metode analisis. Path Analisis dan Pengujian Hipotesis yang diharapkan adalah Ho ditolak atau nilai sig $<0,05$ (atau nilai t statistic $>1,64$ bila ujinya dengan level signifikan 0,05 .

Tabel Path Analisis dan Pengujian Statistik (Pengaruh Langsung)

\begin{tabular}{|l|l|}
\hline & T Statistics $(|\mathrm{O} / \mathrm{STERR}|)$ \\
\hline Kepemimpinan -> Kompensasi & 3.851 \\
\hline Motivasi -> Kompensasi & 2.270 \\
\hline Disiplin Kerja -> Kompensasi & 2.903 \\
\hline Kepemimpinan -> Kinerja Pegawai & 2.642 \\
\hline \hline Kompensasi -> Kinerja Pegawai & 2.791 \\
\hline Disiplin Kerja -> Kinerja Pegawai & 1.980 \\
\hline Motivasi -> Kinerja Pegawai & 0.850 \\
\hline
\end{tabular}


Berdasarkan tabel 4.5 didapatkan hasil yaitu:

(a) Pengaruh variabel Kepemimpinan terhadap Kompensasi dengan nilai t hitung (3.851) $>\mathrm{t}$ tabel $(1,64)$ menunjukkan bahwa pengaruh variabel Kepemimpinan terhadap Kompensasi adalah signifikan. Hal ini berarti hipotesis 1 diterima.

(b) Pengaruh variabel Motivasi terhadap Kompensasi dengan nilai $t$ hitung $(2,270)>t$ tabel $(1,64)$ menunjukkan bahwa pengaruh variabel Motivasi terhadap Kompensasi adalah signifikan. Hal ini berarti hipotesis 2 diterima.

(c) Pengaruh variabel Disiplin Kerja terhadap Kompensasi dengan nilai t hitung $(2,903)$ $>\mathrm{t}$ tabel $(1,64)$ menunjukkan bahwa pengaruh variabel Disiplin Kerja terhadap Kompensasi adalah signifikan. Hal ini berarti hipotesis 3 diterima.

(d) Pengaruh variabel Kepemimpinan terhadap Kinerja Pegawai dengan nilai t hitung $(2,642)>\mathrm{t}$ tabel $(1,64)$ menunjukkan bahwa pengaruh variabel Kepemimpinan terhadap Kinerja Pegawai adalah signifikan. Hal ini berarti hipotesis 4 diterima.

(e) Pengaruh variabel Kompensasi terhadap Kinerja Pegawai dengan nilai t hitung $(2,791)$ $>\mathrm{t}$ tabel $(1,64)$ menunjukkan bahwa pengaruh variabel Kompensasi terhadap Kinerja Pegawai adalah signifikan. Hal ini berarti hipotesis 5 diterima.

(f) Pengaruh variabel Disiplin terhadap Kinerja Pegawai dengan nilai t hitung $(1,980)>t$ tabel $(1,64)$ menunjukkan bahwa pengaruh variabel Disiplin terhadap Kinerja Pegawai adalah signifikan. Hal ini berarti hipotesis 6 diterima.

(g) Pengaruh variabel Motivasi terhadap Kinerja Pegawai dengan nilai t hitung $(0,850)>$ t tabel $(1,64)$ menunjukkan bahwa pengaruh variabel Motivasi terhadap Kinerja Pegawai adalah tidak signifikan. Hal ini berarti hipotesis 7 tidak diterima.

\section{Pengaruh Kepemimpinan Terhadap Kompensasi}

Berdasarkan hasil analisis melalui model persamaan struktural menunjukkan bahwa Kepemimpinan memiliki pengaruh langsung secara positif dan signifikan terhadap Kompensasi dengan nilai $\mathrm{t}$ hitung sebesar $(3,851)>\mathrm{t}$ tabel $(1,64)$. Hipotesis $1\left(\mathrm{H}_{1}\right)$ yang diajukan dalam penelitian ini dapat diterima yaitu semakin baik Kepemimpinan maka semakin baik Kompensasi adalah teruji kebenarannya

Data diatas dipertegas pula dari hasil jawaban responden melalui pertanyaan terbuka yang menyatakan bahwa dengan adanya kenyamanan insfrastruktur akan lebih meningkatkan penyelesaian tugas-tugas yang lebih baik dan akan membuat pelayanan lebih optimal hal ini akan membuat pemberian gaji berjalan dengan lancar dan sesuai dengan waktunya. 
Hasil penelitian lain yaitu penelitian Sunu Waskito Aji (2017) yang berjudul "Analisis Pengaruh Kepemimpinan Dan Kompetensi Terhadap Kinerja Melalui Kompensasi Sebagai Variaberl Intervening" juga menunjukkan hasil Kepemimpinan berpengaruh signifikan dan positif terhadap Kompensasi.

\section{Pengaruh Motivasi Terhadap Kompensasi}

Berdasarkan hasil analisis melalui model persamaan struktural menunjukkan bahwa motivasi memiliki pengaruh langsung secara positif dan signifikan terhadap kompensasi dengan nilai t hitung $(2,270)>\mathrm{t}$ tabel $(1,64)$. Hipotesis $2\left(\mathrm{H}_{2}\right)$ yang diajukan dalam penelitian ini dapat diterima yaitu semakin baik Motivasi maka semakin baik Kompensasi adalah teruji kebenarannya.

Data diatas dipertegas pula dari hasil jawaban responden melalui pertanyaan terbuka yang menyatakan bahwa pemberian gaji yang sesuai dengan waktu yang ditentukan akan membuat para pegawai lebih giat dalam bekerja dan berprestasi untuk mengkatkan kinerja.

Hasil penelitian lain yaitu penelitian Untung Widodo (2015) yang berjudul "Analisis Motivasi Terhadap Kinerja Karyawan Dengan Kompensasi Sebagai Variabel Mediator (Studi Kasus Pada Kantor Kecamatan Gunungpati)” juga menunjukkan hasil Motivasi berpengaruh signifikan dan positif terhadap Kompensasi.

\section{Pengaruh Disiplin Kerja Terhadap Kompensasi}

Berdasarkan hasil analisis melalui model persamaan struktural menunjukkan bahwa disiplin kerja memiliki pengaruh langsung secara positif dan signifikan terhadap kompensasi dengan nilai t hitung $(2,903)>\mathrm{t}$ tabel $(1,64)$. Hipotesis $3\left(\mathrm{H}_{3}\right)$ yang diajukan dalam penelitian ini dapat diterima yaitu Semakin baik Disiplin Kerja maka semakin baik Kompensasi adalah teruji kebenarannya.

Data diatas dipertegas pula dari hasil jawaban responden melalui pertanyaan terbuka yang menyatakan bahwa adanya SOP dalam kedisplinan menjalankan tugas akan membuat pegawai lebih baik lagi dalam mengerjakan tugasnya dan akan memperlancar pemberian gaji para pegawai.

Hasil penelitian lain yaitu penelitian Ali Shultoni (2016) yang berjudul "Pengaruh Motivasi, Jenjang Karir, Disiplin Kerja Terhadap Kinerja Karyawan Dengan Kompensasi Variabel Intervening” juga menunjukkan hasil Disiplin Kerjaberpengaruh signifikan dan positif terhadap Kompensasi. 


\section{Pengaruh Kepemimpinan Terhadap Kinerja Pegawai}

Berdasarkan hasil analisis melalui model persamaan struktural menunjukkan bahwa Kepemimpinan memiliki pengaruh langsung secara positif dan signifikan terhadap Kinerja Pegawai dengan nilai $t$ hitung $(2,642)>\mathrm{t}$ tabel $(1,64)$. Hipotesis $4\left(\mathrm{H}_{4}\right)$ yang diajukan dalam penelitian ini dapat diterima yaitu semakin baik Kepempinan maka semakin baik Kinerja Pegawai adalah teruji kebenarannya.

Data diatas dipertegas pula dari hasil jawaban responden melalui pertanyaan terbuka yang menyatakan bahwa dalam meningkatkan kemampuan Sumber Daya Manusia dalam mengulang kembali menambah wawasan pimpinan selalu mengadakan pemberian pelatihan untuk memperbaiki dan memperluas wawasan pegawai dalam meningkatkan kinerja pegawai.

Hasil penelitian lain yaitu penelitian Adi Suryadharma (2016) yang berjudul "Pengaruh Kepemimpinan dan Kompensasi Terhadap Kepuasan Kerja dan Kinerja Karyawan (Studi Pada PT. BPR Sri Artha Lestari Denpasar)” juga menunjukkan hasil Kepemimpinan berpengaruh signifikan dan positif terhadap Kinerja Pegawai.

\section{Pengaruh Kompensasi Terhadap Kinerja Pegawai}

Berdasarkan hasil analisis melalui model persamaan struktural menunjukkan bahwa Kompensasi memiliki pengaruh langsung secara positif dan signifikan terhadap Kinerja Pegawai dengan nilai $\mathrm{t}$ hitung $(2,791)>\mathrm{t}$ tabel $(1,64)$. Hipotesis $5\left(\mathrm{H}_{5}\right)$ yang diajukan dalam penelitian ini dapat diterima yaitu Semakin baik Kompensasi maka semakin baik Kinerja Pegawai adalah teruji kebenarannya.

Data diatas dipertegas pula dari hasil jawaban responden melalui pertanyaan terbuka yang menyatakan bahwa dengan diterimanya gaji dan THR tepat waktu serta dengan adanya BPJS dan fasilitas yang menjamin akan membuat para pegawai bekerja sesuai dengan targetnya.

Hasil penelitian lain yaitu penelitian Untung Widodo (2015) yang berjudul "Analisis Motivasi Terhadap Kinerja Karyawan Dengan Kompensasi Sebagai Variabel Mediator (Studi Kasus Pada Kantor Kecamatan Gunungpati)" juga menunjukkan hasil Kompensasi berpengaruh signifikan dan positif terhadap Kinerja Pegawai.

\section{Pengaruh Disiplin Kerja Terhadap Kinerja Pegawai}

Berdasarkan hasil analisis melalui model persamaan struktural menunjukkan bahwa Disiplin Kerja memiliki pengaruh langsung secara positif dan signifikan terhadap Kinerja Pegawai dengan nilai $t$ hitung $(1,980)>\mathrm{t}$ tabel $(1,64)$. Hipotesis $6\left(\mathrm{H}_{6}\right)$ yang diajukan dalam penelitian ini dapat diterima yaitu Semakin baik Disiplin Kerja maka semakin baik Kinerja 
Pegawai adalah teruji kebenarannya.

Data diatas dipertegas pula dari hasil jawaban responden melalui pertanyaan terbuka yang menyatakan bahwa dengan mentaati aturan dalam berdisiplin waktu, berpakaian, aturan dan pelaksanaan tugas akan membuat kualitas kerja dapat dicapai dengan baik.

Hasil penelitian lain yaitu penelitian Siti Noer Istiqomah (2015) yang berjudul “. Pengaruh Disiplin Kerja dan Iklim Komunikasi Terhadap Kinerja Pegawai Dinas Perhubungan Kota Yogyakarta dengan Motivasi Kerja Sebagai Variabel Intervening” juga menunjukkan hasil Disiplin Kerja berpengaruh signifikan dan positif terhadap Kinerja Pegawai.

\section{Pengaruh Motivasi Terhadap Kinerja Pegawai}

Berdasarkan hasil analisis melalui model persamaan struktural menunjukkan bahwa Motivasi memiliki pengaruh langsung secara positif dan tidak signifikan terhadap Kinerja Pegawai dengan nilai $\mathrm{t}$ hitung $(0,850)>\mathrm{t}$ tabel $(1,64)$. Hipotesis $7\left(\mathrm{H}_{7}\right)$ yang diajukan dalam penelitian ini dapat diterima yaitu Semakin baik Motivasi maka semakin baik Kinerja Pegawai adalah tidak teruji kebenarannya.

Data diatas dipertegas pula dari hasil jawaban responden melalui pertanyaan terbuka yang menyatakan bahwa adanya penghargaan dan target perencanaan yang tepat para pegawai semakin semangat dalam meningkatkan kinerjanya maka dengan adanya penghargaan dan target perencanaan para pegawai akan lebih maksimal dalam menyelesaikan pekerjaannya.

\section{PENUTUP}

Berdasarkan hasil penelitian dan pembahasan sebelumnya, dapat ditarik kesimpulan bahwa Kepemimpinan, Kompensasi, Disiplin Kerja, Motivasi dan Kinerja Pegawai. Hasil penelitian ini diharapkan dapat memberikan sumbangan yang berarti dalam pengembangan ilmu ekonomi, khususnya pada bidang ilmu manajemen sumber daya manusia. Hasil penelitian ini juga diharapkan dapat menjadi bahan refrensi dan perbandingan untuk penelitian-penelitian selanjutnya yang berkaitan dengan Kepemimpinan, Kompensasi, Disiplin Kerja, Motivasi dan Kinerja Pegawai. Selain itu, hasil penelitian ini diharapkan memberi kontribusi implikasi kebijakan Kantor Regional X Badan Kepegawaian Negara Denpasar untuk memberikan kesempatan kepada pegawai untuk mengembangkan kemampuan diri untuk berprestasi. Penelitian ini memiliki keterbatasan. Oleh karena itu untuk peneliti berikutnya agar dapat menambahkan indikator pada setiap variabel sehingga informasi yang diperoleh diharapkan lebih mendalam. 


\section{DAFTAR PUSTAKA}

Artikel Sosiologi . (2015). Pengertian Kepemimpinan, Fungsi, Sejarah Kepemimpinan. (http://www.artikelsiana.com).

Artikel Siana. (2017). Pengertian Kompensasi, Tujuan, Komponen \& Jenis-Jenis Kompensasi. (http://www.artikelsiana.com).

Aji, S.W. (2017). Analisis Pengaruh Kepemimpinan Dan Kompetensi Terhadap Kinerja Melalui Kompensasi Sebagai Variaberl Intervening (Survei pada Karyawan PT Wahana Sun Solo).

Angka, A.T., and Darma, G.S. (2016). The Impact of Leadership Style on Employee's Satisfaction, Jurnal Manajemen \& Bisnis, 13 (1): 78-91.

Bandeni. (2014). Kepemimpinan \& Perilaku Organisasi. Bandung: Alfabeta.

Buchari, Z. (2007). Manajemen dan Motivasi, Edisi Revisi, Cetakan ke 3. Jakarta: Balai Aksara.

Blog Pendidikan Indonesia. (2013). Pengertian Pengukuran Kerja Tujuan. (http://www.sarjanaku.com).

Dale, R. D. (1992). Pelayan Sebagai Pemimpin. Malang: Gandum Mas.

Dewi, A.A.I.S., and Darma, G.S. (2017). Proses Rekrutmen, Seleksi, Pelatihan, Penempatan dan Kinerja Karyawan, Jurnal Manajemen \& Bisnis, 14 (1): 1-18.

Dewi, N.M.A.T., and Darma, G.S. (2016). Efektivitas Leadership, Growth Performance dan Regulasi Otoritas Jasa Keuangan, Jurnal Manajemen \& Bisnis, 13 (1): 1-13.

Emron, E., Anwar, Y., dkk. (2016). Manajemen Sumber Daya Manusia. Bandung: Alfabeta.

Fathoni, A. (2006). Manajemen Sumber Daya Manusia. Bandung: Rineka. Cipta.

Gary, A. (2005). Manajemen Sumber Daya Manusia, Edisi Bahasa Indonesia Jilid 2. PT. Macana Jaya Cemerlang.

Ghozali, I. (2006). Structural Equation Modelling Metode Alternatif dengan Partial Least Square. Edisi Kedua. Semarang: Universitas Diponegoro.

Handoko, H. (2011). Manajemen Personalia dan Sumberdaya Manusia. Yogyakarta: BPFE.

Hasibuan, M. (2011). Manajemen Sumber dan Daya Manusia. Edisi Revisi. Jakarta: Bumi Aksara.

Harian Umat. (2017). Pengertian Kinerja Menurut Para Ahli. (http://www.landasanteori.xyz) Hasibuan, H.M. (2003). Manajemen Sumber Daya Manusia. Jakarta: Bumi Aksara.

Hariyanto. (2010). Pengertian Kepemimpinan Menurut Para Ahli. (http://belajarpsikologi.com). 
Hasibuan. (2003). Dasar Kunci Keberhasilan Manajemen Sumber Daya Manusia.

Istiqomah, S.N. (2015). Pengaruh Disiplin Kerja dan Iklim Komunikasi Terhadap Kinerja Pegawai Dinas Perhubungan Kota Yogyakarta dengan Motivasi Kerja Sebagai Variabel Intervening.

Indiantoro, N., dan Bambang Supomo. (1999). Metodologi Penelitian Bisnis. Jogjakarta: BPFE.

Julianry, A. (2017). Pengaruh Pelatihan dan Motivasi Terhadap Kinerja Karyawan Serta Kinerja Organisasi Kementerian Komunikasi dan Informatika. Bogor: Sekolah Bisnis, Institut Pertanian Bogor.

Kaplan, R.S., \& David P. Norton. (1996). The Balanced Scorecard: translating strategy into action. Massachusetts: Harvard Business School Press.

Luthans, F. (2005). Organizational Behavior. New York: McGraw-hill.

Mangkunegara, P.A. (2000). Evaluasi Kinerja Sumber Daya Manusia. Jakarta: Refika Aditama.

Mariani, L.M.I. (2017). Pengaruh Motivasi, Komunikasi dan Disiplin Kerja terhadap Kinerja Karyawan Warung Mina Peguyangan di Denpasar. Denpasar: Fakultas Ekonomi dan Bisnis Universitas Udayana.

Mathis, R.L., \& J.H. Jackson. (2006). Human Resource Management: Manajemen Sumber Daya Manusia. Terjemahan Dian Angelia. Jakarta: Salemba Empat.

Nimran, U. (2005). Perilaku Organisasi. Surabaya: Citra Media.

Nugroho, C.A. (2015). Pengaruh Gaya Kepemimpinan dan Disiplin Kerja terhadap Kinerja Pegawai Dinas Pariwisata DIY. Yogyakarta: Fakultas Ekonomi Universitas Negeri Yogyakarta.

Nugroho, B.A. (2005). Strategi Jitu Memilih Metode Statistik Penelitian dengan SPSS.Yogyakarta: Andi.

Nurlaila. (2010). Manajemen Sumber Daya Manusia I. LepKhair.

Psychology Mania. (2012). Tujuan Pemberian Kompensasi.

(https://www.psychologymania.com).

Rijal. (2016). Pengertian Motivasi. (http://www.rijal09.com).

Rivai, V., \& Basri. (2005). Peformance Appraisal: Sistem yang tepat untuk Menilai Kinerja Karyawan dan Meningkatkan Daya Saing Perusahan. Jakarta: PT. RajaGrafindo Persada.

Robbin, P.S. (2003). Perilaku Organisasi, Alih Bahasa, Tim Indeks. Jakarta: Gramedia. 
Robbins, S.P. (2006). Perilaku Organisasi. Jakarta: PT Indeks, Kelompok Gramedia.

Rudlia, J.I. (2016). Pengaruh Kompetensi dan Kompensasi terhadap Kepuasan Kerja dan Kinerja Pegawai (Studi Kasus Pada Dinas Kelautan dan Perikanan Kabupaten Kepulauan Sangihe), Jurnal Riset Bisnis dan Manajemen, 4 (3): 257-268.

Riyadi, S. (2011). Pengaruh Kompensasi Finansial, Gaya Kepemimpinan, dan Motivasi Kerja Terhadap Kinerja Karyawan pada Perusahaan Manufaktur di Jawa Timur.

Robbins, S.P., Judge, T.A. (2008). Perilaku Organisasi, Buku 2, Edisi 12. Jakarta: Salemba Empat.

Sukmasari P, H. (2011). Pengaruh Kepemimpinan, Motivasi, Insentif, Lingkungan Kerja dan Kepuasan Kerja Terhadap Kinerja Pegawai Dinas Pengelolaan Keuangan dan Aset Daerah Kota Semarang.

Supomo, R., Nurhayati, E. (2018). Manajemen Sumber Daya Manusia. Bandung: Yrama Widya.

Setiawan, A.A. (2015). Teknik Analisis Data. (http://eprints.uny.ac.id)

Shultoni, A. (2016). Pengaruh Motivasi, Jenjang Karir, Disiplin Kerja Terhadap Kinerja Karyawan Dengan Kompensasi Variabel Intervening.

Sutrisno, E. (2013). Manajemen Sumber Daya Manusia. Jakarta: Kencana.

Sinambela, L.P. (2017). Manajemen Sumber Daya Manusia. Jakarta: Bumi Aksara.

Sastrohadiwiryo, B. Siswanto. (2003). Manajemen Tenaga Kerja Indonesia, edisi 2. Jakarta: PT. Bumi Aksara.

Sardiman, AM. (2005). Interaksi dan Motifasi Belajar Mengajar. Jakarta: PT Raja Grafindo Persada.

Shultoni, A. (2016). Pengaruh Motivasi, Jenjang Karir, Disiplin Kerja Terhadap Kinerja Karyawan Dengan Kompensasi Variabel Intervening.

Sopiah. (2008). Perilaku Organisasional. Yogyakarta: C.V Andi Offset.

Thoha, M. (2004). Perilaku Organisasi: Konsep Dasar dan Aplikasinya. Jakarta: Raja Grafindo Persada.

Umar, H. (2000). Metode Penelitian untuk Skripsi dan Tesis Bisnis. ed. Baru, cetakan 3, Jakarta: PT. RajaGrafindo Persada.

Widodo, U. (2015). Analisis Motivasi Terhadap Kinerja Karyawan Dengan Kompensasi Sebagai Variabel Mediator (Studi Kasus Pada Kantor Kecamatan Gunungpati). 
Wiandari, I.A.A., and Darma, G.S. (2017). Kepemimpinan, Total Quality Management, Perilaku Produktif Karyawan, Kinerja Karyawan dan Kinerja Perusahaan, Jurnal Manajemen \& Bisnis, 14 (2): 61-78.

Widiatmika, P.H., and Darma, G.S. (2018). Good Corporate Governance, Job Motivation, Organization Culture Which Impact Company Financial Performance, Jurnal Manajemen \& Bisnis, 15 (3): 82-99.

Wulansari, D., Prasetio. (2014). Pengaruh Kompensasi Terhadap Motivasi Karyawan Di Departemen Sumber Daya Manusia PLN Kantor Distribusi Jawa Barat dan Banten.

Yudiastra, P.P., and Darma, G.S. (2015). Pengaruh Penggunaan Teknologi Informasi, Disiplin Kerja, Insentif, Turnover Terhadap Kinerja Pegawai, Jurnal Manajemen \& Bisnis, 12 (1): $156-172$. 